\title{
SPIDER CRABS OF THE GENERA PARATYMOLUS MIERS, 1879 AND LITOSUS LOH \& NG, 1999 FROM LOMBOK ISLAND, INDONESIA (CRUSTACEA, DECAPODA, BRACHYURA, MAJOIDEA, INACHIDAE)
}

\author{
Dwi Listyo Rahayu \\ Marine Bioindustry Implementation Unit \\ Research Centre for Oceanography-Indonesian Institute of Sciences (LIPI) \\ P.O. Box 1124 Mataram 83000, NTB, Indonesia \\ E-mail:dwilistyo@yahoo.com
}

Received: September 2010

Accepted: February 2011

\begin{abstract}
A small collection of majoid spider crabs of the genus Paratymolus Miers, 1879, s.l from Lombok Island, Indonesia contains four species namely P. hastatus Alcock (1895), P. coccus Loh \& Ng (1999), P. cygnus Loh \& $\mathrm{Ng}$ (1999), and Litosus sexspinosus (Miers, 1884). Except for L. spinosus, the three other species are new records for Indonesia. Paratymolus coccus is previously known from only female specimens, and the presence of male specimens in the collection studied provides the opportunity to complete the description of male characters. Paratymolus hastatus is reported for the first time outside Indian Ocean and P. cygnus is recorded for the first time after its description.
\end{abstract}

Keywords: Inachidae, Paratymolus s.l., Lombok Island

\section{INTRODUCTION}

The taxonomy of the genus Paratymolus Miers, 1879 sensu lato (s.l) has been revised and its species are restricted by Loh \& $\mathrm{Ng}$ (1999) with some species assignes to Dumea Loh \& Ng (1999), and Litosus Loh \& Ng (1999). These genera are members of subfamily Inachinae, family Majidae, superfamily Majoidea. However, the subfamily Inachinae is now erected to family Inachidae $(\mathrm{Ng}$ et al, 2008).

Currently the genus Paratymolus sensu stricto $(s . s)$ is defined by its ovoid to distinctly pentagonal carapace, absent or poorly formed antorbital angle of supraorbital eave, and the presence of gastric and cardiac tubercles, and two or three large teeth on the ventral margin of ambulatory legs. Dumea is characterized by its broadly pentagonal carapace, the presence of anterorbital angle of supraorbital eave, absence of gastric and cardiac tubercles, anterolateral margin armed with three large spines and two smaller ones in between; while Litosus is recognized by broadly pentagonal carapace, the absence of anterorbital angle of supraorbital eave and gastric and cardiac tubercles, and the presence of one broadly tubercles followed by an anteriorly-directed spine on the anterolateral margin (Loh \& Ng, 1999). Within each genus, congeners are often superficially similar externally, with the main differences in the morphology of the male first gonopod (Loh \& Ng, 1999).

Paratymolus s.l from Indonesia is currently represented only by $P$. bituberculatus Haswell (1880) (as P. pubescens, reported from Sumbawa and Maluku) and Litosus sexspinosus (Miers, 1884) (as $P$. sexspinosus reported from Aru, Maluku), as reported by Griffin \& Tranter (1986). Although it was stated that the material of these two species was deposited at the Research Center for Oceanography (formerly National Institute of Oceanology), they cannot be located and the present identification is based on the drawings of male first gonopods by Griffin and Tranter (1986: 39 , figure $7 \mathrm{f}, \mathrm{g}$ ). 
The present study deals with small collection of Paratymolus s.l from Lombok Island that contained four species namely Paratymolus hastatus Alcock (1895), P. coccus Loh \& Ng (1999), $P$. cygnus Loh \& Ng (1999), and Litosus sexspinosus. Except for $L$. sexspinosus, the other three species are new records for Indonesia. Paratymolus hastatus has previously only been reported from Indian Ocean, and P. cygnus only from Singapore. Paratymolus coccus so far is known only from female specimens from Okinawa, Japan, and the presence of male specimens in this collection provides the opportunity to complete the description of male characters.

The material examined is deposited in the Museum Zoologi, Bogor, Indonesian Institute of Sciences (MZB) and Zoological Reference Collection of the Raffles Museum for Biodiversity Research, National University of Singapore (ZRC). The terminology for diagnosis followed that of Loh \& $\mathrm{Ng}$ (1999). Carapace length (cl) in millimeter is measured from a point on the line joining the preorbital angle of supraorbital eave to the center of posterior margin of the carapace. Ovigerous is abbreviated as ovig.

\section{TAXONOMY}

\section{Paratymolus hastatus Alcock, 1895}

(Figure 1A)

Paratymolus hastatus Alcock, 1895: 174, pl. V, figure 4, 4a; Laurie, 1906: 370; Loh \& Ng, 1999: 378, figure 4; $\mathrm{Ng}$ et al., 2008: 112.

Paratymolus pubescens - Barnard, 1955: 9 (not $P$. pubescens Miers, 1879)

Material examined. Teluk Kombal, Lombok Island, $08^{\circ} 24.114^{\prime}, 116^{\circ} 07.606^{\prime}, 14$ June 2007: 1 female (cl. $3.3 \mathrm{~mm}$ ), 2 female ovig. (cl. $3.1 \mathrm{~mm}$, $3 \mathrm{~mm}$ ) (MZB); Kuta, Lombok Island, 19 August 2006: 1 female ovig. (4.5 mm) (ZRC).

Remarks. As discussed by Loh \& Ng (1999), many of the species in the genus Paratymolus closely resembled each other in external morphology, and the most effective character to separate the species was the structure of the first male gonopod. However, without the presence of male specimens in this present study, P. hastatus could still be easily recognized by the prominent anterior gastric tubercles and the presence of two or three tubercles on the posterior lateral margin. Certainly, when males became available, the male gonopod characters should be checked.

The specimens were collected from a seagrass bed, the substrate was composed of white sand and shells debris.

Distribution. Reported only from Indian Ocean (Andaman Sea, Sri Lanka, and South India). The Lombok record represents a considerable southward extension in range for the species.

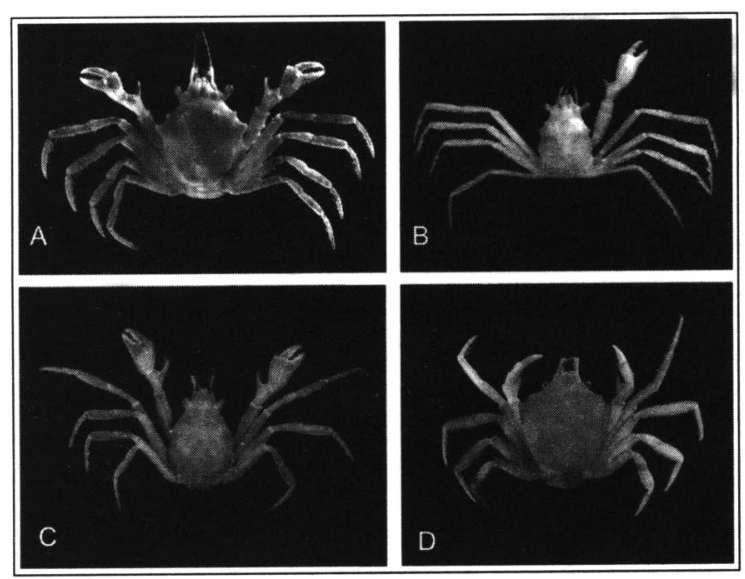

Figure 1. A. Paratymolus hastatus Alcock, 1895, female (cl $3.3 \mathrm{~mm})$. B. Paratymolus coccus Loh \& Ng, 1999, male (cl. 4.6 mm). C. Paratymolus cygnus Loh \& $\mathrm{Ng}, 1999$, male (cl. $3.3 \mathrm{~mm}$ ), left cheliped missing. D. Lisosus sexspinosus (Miers, 1884), male (cl. $5.1 \mathrm{~mm}$ ).

\section{Paratymolus coccus Loh \& Ng, 1999}

(Figure 1B, 2)

Paratymolus coccus Loh \& Ng, 1999: 382, figure 6; Ng et al., 2008: 112.

Material examined. Tanjung Sira, Lombok Island, $08^{\circ} 21.64^{\prime}, 116^{\circ} 06.272 ', 13$ June 2007, 2 males (cl. $4.3 \mathrm{~mm}, 4.6 \mathrm{~mm}$ ) (ZRC, MZB).

Diagnosis. Anterior gastric tubercles very low, almost indiscernible; posterior gastric and cardiac regions not elevated, each with very faint tubercles. No ridge discernible on dorsal branchial region.

Anterolateral margin with very low tubercles followed by slightly curved, sharp spine; posterior lateral margin with low tubercle. Merus of cheliped (Figure 2D) with 3 spinules on anterior margin, 
stronger distally; outer surface of carpi and palms with 2 or 3 low tubercles; carpal spine not hidden behind palm when cheliped apposed against carapace. First ambulatory leg 2.1 times carapace length; legs slender, with 2 large curved spines on ventral margin of dactylus, denticles not discernible. Male first gonopod (Figure 2F, G, H, I) stout, broad at base, distal portion slightly bent, long, simple, with long and dense setae proximally.

Remarks. Paratymolus coccus was described by Loh \& $\mathrm{Ng}$ (1999) from two ovigerous female specimens. The male specimens in this collection were assigned to $P$. coccus because of the characteristic shape and tuberculation of the carapace. However, the male carapace was relatively narrower, with blunter and relatively indistinct tubercles, and the cheliped and ambulatory legs

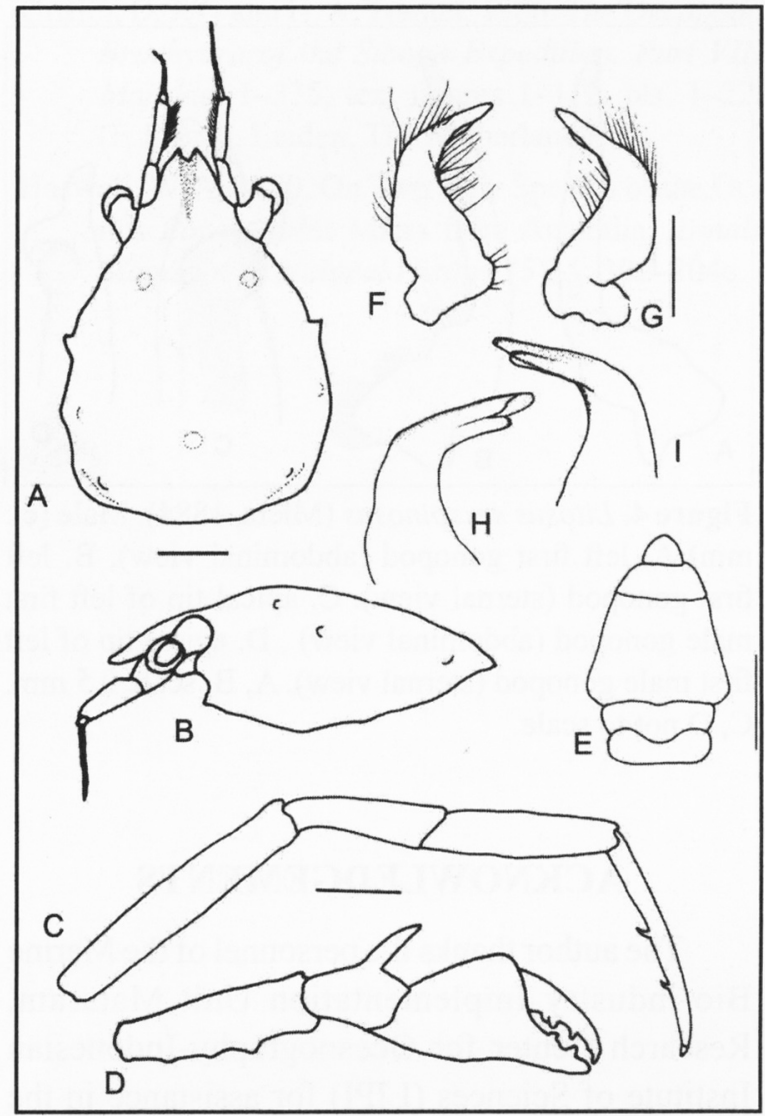

Figure 2. Paratymolus coccus Loh \& Ng, 1999, male (cl. $4.6 \mathrm{~mm}$ ). A. carapace (dorsal view), B. carapace (lateral view), C. right fifth pereopod, D. left cheliped, E, abdomen. F, left first male gonopod (abdominal view), G. left first male gonopod (sternal view), H. apical tip of first male gonopod (abdominal view). I. apical tip of first male gonopod (sternal view). A-E scale $1 \mathrm{~mm}$. F, G. scale $0.5 \mathrm{~mm}$. H, I not to scale. were proportionately longer in relation to the carapace length compared to the female holotype. These differences were considered to be within the range of sexual dimorphism observed in the genus (Loh \& Ng, 1999).

This species was reported to be a coral dweller in Okinawa, Japan (Loh \& Ng, 1999). In Indonesia, it was collected from a seagrass ecosystem, the substrate consisting of sand and mud with coral and shell debris.

Distribution. The only record was the types from Okinawa, Japan. The discovery of this species in Lombok Island, Indonesia, expands its distribution southward.

\section{Paratymolus cygnus Loh \& Ng, 1999}

(Figure 1C, 3)

Paratymolus cygnus Loh \& Ng, 1999: 384, figure 7.

Paratymolus pubescens Rathbun, 1910: 317 (part); Griffin \& Tranter, 1986: 38, figure 7d (part); Ng et al., 2008: 112.

Material examined. Ekas, Lombok Island, 14 May 2007. 2 males (cl. $3.3 \mathrm{~mm}, 2.6 \mathrm{~mm}$ ); 1 female ovig. (cl. $2 \mathrm{~mm}$ ), 2 females (cl. $3.8 \mathrm{~mm}, 3.3 \mathrm{~mm}$ ) (MZB).

Remarks. The present specimens agreed well with description of the species by Loh \& Ng (1999). The structure of the male first gonopod (Figure 3 ), however, was slightly different in shape, with the distal part relatively wider and more expanded.

In Singapore this species lives intertidally, along sandy-rocky beach, with exposed coral head or coral rock with algae (Loh \& Ng, 1999). In Lombok Island it was collected in sandy-rocky beach with seagrass growth.

Distribution. Sentosa reef, Singapore, and Lombok Island, Indonesia. 


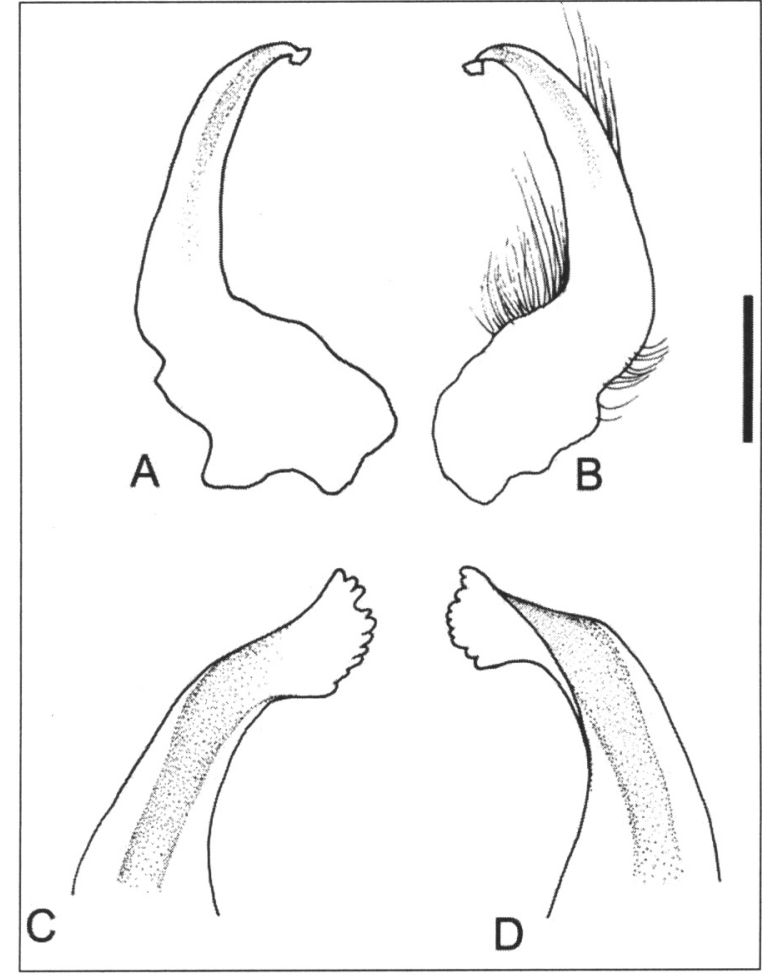

Figure 3. Paratymolus cygnus Loh \& Ng, 1999. male (cl. $3.3 \mathrm{~mm}$ ), A, left first gonopod (abdominal view), B. left first gonopod (sternal view). C. apical tip of left first male gonopod (abdominal view), D. apical tip of left first male gonopod (sternal view). A, B, scale 0.5 $\mathrm{mm}$. C, D not to scale.

\section{Litosus sexspinosus (Miers, 1884)}

(Figure 1D, 4)

Paratymolus sexspinosus Miers, 1884 : 261, pl. 27, figure B ; Henderson, 1893: 352 ; Calman, 1899: 33 ; Griffin, 1966: 276 (in key) ; Griffin \& Tranter, 1986: 42, figure 7 f, g ; Dai \& Yang, 1991: 120.

Litosus sexspinosus - Loh \& Ng, 1999: 399, figure 13, 14; Ng et al., 2008: 112.

Material examined. Kuta, Lombok, 19 August 2006, 3 females (cl. $6.4 \mathrm{~mm}, 6.8 \mathrm{~mm}, 8.2 \mathrm{~mm}$ ), 1 female (cl. $7.45 \mathrm{~mm})$. Teluk Nara, Lombok Island, $08^{\circ} 24.234^{\prime}, 116^{\circ} 04.274^{\prime}, 14$ June 2007,1 male (cl. $5.1 \mathrm{~mm}$ ), 1 female (cl. $6.5 \mathrm{~mm}$ ). Kecinan, Lombok Island, $08^{\circ} 24.368^{\prime}, 116^{\circ} 03.561^{\prime}, 14$ June 2006,1 male (cl. $4.8 \mathrm{~mm}$ ) (MZB).

Remarks. In Indonesian waters, this species was reported by Griffin \& Tranter (1986) from Aru Island as P. sexspinosus. Loh \& Ng (1999) established the genus Litosus for this species, separated from Paratymolus, by the shape of carapace, the form of the ocular peduncles, the chelipeds, the ambulatory legs and the male abdomen. Two species included in the genus: L. sexspinous and L. girrafus Loh \& Ng (1999).

Litosus sexspinosus was easily separated from its congener by the hooked structure on the apical process of the first male gonopod. The first male gonopod (Figure 4) of the male specimens in this study resembled the largest male drawn by Loh \& $\mathrm{Ng}$ (1999: 401, figure $14 \mathrm{E}, \mathrm{F}$ ), but with the hook was a bit more pronounced.

In Lombok Island this species was collected from intertidal area on seagrass bed. Loh \& $\mathrm{Ng}$ reported it from littoral zone on seaweed and coral rock up to $15 \mathrm{~m}$.

Distribution. India, Indonesia (Aru and Lombok Island), Australia, Singapore, and China.

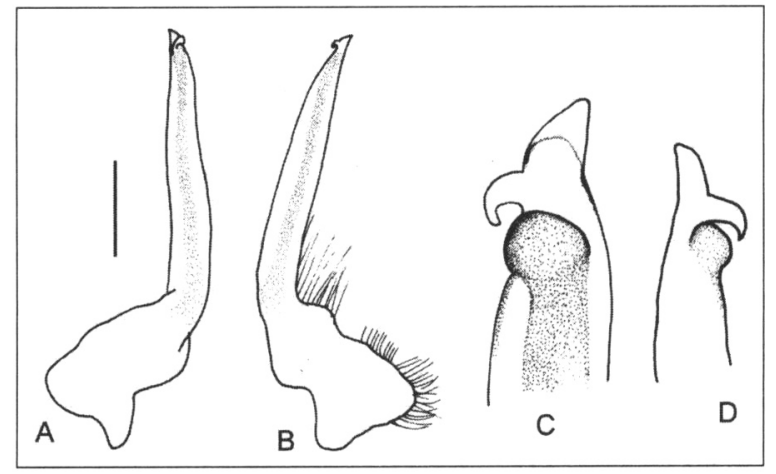

Figure 4. Litosus sexspinosus (Miers, 1884). Male (cl. $\mathrm{mm}$ ) A, left first gonopod (abdominal view), B. left first gonopod (sternal view). C. apical tip of left first male gonopod (abdominal view), D. apical tip of left first male gonopod (sternal view). A, B, scale $0.5 \mathrm{~mm}$ C, D not to scale.

\section{ACKNOWLEDGEMENTS}

The author thanks the personnel of the Marine Bio-industry Implementation Unit Mataram, Research Center for Oceanography-Indonesian Institute of Sciences (LIPI) for assistance in the collection of the materials for this study. The efforts of Rianta Pratiwi to find the specimens of Paratymolus supposedly deposited by Griffin and Tranter (1986) in the collection of the Research Center for Oceanography is much appreciated. The review by P.K.L. Ng from Raffles Museum of Biodiversity Research, National University of 
Singapore and T. Naruse from the University of Ryukyu, Okinawa, Japan improved the manuscript.

\section{REFERENCES}

Alcok, A. 1895. Materials for a Carcinological Fauna of India. 1. The brachyuran Oxyrhyncha. Journal of the Asiatic Society of Bengal, 64: 157-291.

Barnard, K. H. 1955. Additions to the Fauna List of South African Crustacea and Pygnogonida. Annals of South Africa Museum, 48: 1-107, figs. $1-53$.

Calman, W. T. 1900. On a Collection of Brachyura from Torres Straits. Transactions of the Linnean Society London, Zoology (2) 8: 1-50.

Dai, A. and S. Yang. 1981. Crabs of the China Seas. Beijing: China Ocean Press (Beijing). 682pp.

Griffin, D. J. G. 1966. A Review of the Australian Majid Spider Crabs (Crustacea, Brachyura). Australian Zoology 13: 259-298.

Griffin, D. J. G and H. A. Tranter. 1986. The Decapoda Brachyura of the Siboga Expedition. Part VIII Majidae: 1-335, text figures 1-112, pls. 1-22. (E.J. Brill, Leiden, The Netherlands)

Haswell, W. A. 1880. On Two New Species of the Genus Paratymolus Miers from Australia. Annals Magazine of Natural History (5), 5: 302-304e.
Henderson, J. R. 1893. A Contribution to Indian Carcinology. Transactions of the Linnean Society London, Zoology (20) 5: 325-458.

Laurie, E. D. 1906. Report on the Brachyura collected by Professor Herdman, at Ceylon in 1902. Report of Ceylon Pearl Oyster Fisheries, 5, Supplement Report 40: 349-432.

Loh, L. W. and P. K. L. Ng. 1999. A Revision of the Spider Crabs of the Genus Paratymolus Miers, 1897, with Descriptions of Two New Genera and Six New Species (Crustacea: Decapoda: Brachyura: Majidae). Raffles Bulletin of Zoo$\log y, 47$ (2): 365-407.

Miers, E. J. 1884. Crustacea. In: Report on the Zoological Collection Made in the Indo-Pacific Ocean during the Voyage of H. M. S. Alert 1881-1882: 178-322, 513-575.

Ng, P. K. L., D. Guinot and P. J. F. Davie. 2008. Systema Brachyurorum: Part I. An Annotated Checklist of Extant Brachyuran Crabs of the World. Raffles Bulletin of Zoology, Supplement 17: 1-286.

Rathbun, M. J. 1910. The Danish Expedition to Siam 1899-1900, 5. Brachyura. Kgl. Danske Vidensk. Selsk. Skrifter (7), 5: 303-367. 